\title{
IMPROVEMENT OF POSSIBILITIES OF TREATING PNEUMONIAS IN PATIENTS ON THE BACKGROUND OF ACUTE MYELOBLAST LEUCOSIS IN THE ASPECT OF IMMUNORESISTANCE MECHANISMS
}

\author{
Inna Borisova \\ Department of Medical and Social Examination and Rehabilitation \\ SE «Dnipropetrovsk Medical Academy of Health Ministry of Ukraine» \\ 9 V. Vernadskogo str., Dnipro, Ukraine, 49044 \\ doctorinnaborisova1@gmail.com
}

\begin{abstract}
Aim: to analyze the influence of the immunomodeling preparation glutamyl-cysteinyl-glycine disodium (glutoxim) on indices of cellular and humoral immunity in patients with pneumonias on the background of acute myeloblast leucosis to form new approaches to the improvement of treating pneumonias in patients with immunity disorders.

Materials and methods. The research group - 37 patients with pneumonia on the background of acute myeloblast leucosis, who underwent the program treatment on the base of the hematological center "MI city multi-profile clinical hospital No. 4" Dnipro city, 2014-2015. The age of patients from 23 to 45 years old; 10 women and 27 men. The diagnosis of leucosis and pneumonia forms was verified corresponding to modern conventional clinical and morphological criteria. Patients from the main research group ( $\mathrm{n}=18)$ were prescribed with glutamyl-cysteinyl-glycine disodium by the scheme $2 \mathrm{ml}$ of $3 \%(60 \mathrm{mg}) \mathrm{i} / \mathrm{v}$ No. 10 in mornings, summary dose $-300 \mathrm{mg}$. Indications of immunograms were studied: T-lymphocytes, B-lymphocytes and their subpopulation composition (CD3+, CD4+, CD8+, CD19+, CD19-, CD16+, CD56+) using the flowing laser cytofluorimetry. Immunoglobulin levels were determined by the method of immunoturbometry. Indications of immunograms were assessed in the treatment dynamics. The statistical processing - using packages of applied programs «Excel» and «Statistic 10».

Results. According to the analysis of indices of the cellular and humoral immunity of patients with pneumonia on the background of acute myeloblast leucosis, the process of glutamyl-cysteinyl-glycine disodium use proved the statistically reliable activation of phagocytosis and anti-infectious defense indices. The dynamics of humoral immunity indices also proved the positive influence on the state of the immune reactivity of the organism with the reliable increase of IgA and Ig M, responsible for neutralization of infectious agents and bacterial toxins.

Conclusions: The use of the ummunomodeling preparation glutamyl-cysteinyl-glycine disodium (glutoxim) in patients with pneumonia on the background of acute myeloblast leucosis results in the improvement of indices of cellular and humoral immunity and phagocytosis activation. The research results prove the possibility of optimization of approaches to treating pneumonias in patients with severe immunity disorders by using immunomedeling therapy by glutamyl-cysteinyl-glycine disodium (glutoxim).
\end{abstract}

Keywords: pneumonia, myeloblast leucosis, glutamyl-cysteinyl-glycine disodium, cellular and humoral immunity indices.

\section{Introduction}

The pathogenetic background of acute leucosis (AL) is a cellular immunity defect, manifested by the change of quantitative indices and functional disability of T-lymphocytes and monocytic-phagocytic system. Immunity disorders in patients with AL are conditioned also by treating methods. The wide use of anti-tumor chemotherapy at AL leads to different side effects. Infectious complications remain the most often and most severe among all ones in oncohematologic patients during the program treatment, and are often the direct cause of their death [1]. Corticosteroids, combined with cytostatics negatively influence the patient's immunity state. On this background severe infectious-inflammatory complications, including pneumonias that often result in patients' death are observed in patients with AL in more than $50 \%$ cases [2]. The incorrect antibacterial therapy also intensifies the expressiveness of the immunodeficiency syndrome and leads to the formation of resistant nosocomial flora that is very difficultly subjected to elimination in patients with pneumonia on the background of AL [3]. In this connection the strategy of using only etiotropic antibacterial therapy (ABT) at pneumonias in patients with AL doesn't lead to expected results. 
For increasing the effectiveness of treating pneumonia in patients with AL, immunotherapy which main aim - to help the immune system to attack tumor cells by the immunity stimulation, is used more and more often in the last years.

Glutamyl-cysteinyl-glycine disodium - is a chemically synthesized biologically active compound - hexapeptide with the stabilized disulphide connection (bis-(gamma-L-glumamyl)-cysteinyl-bis-glycine-disodium salt) with the general formula $-\mathrm{C}_{20} \mathrm{H}_{32} \mathrm{O}_{16} \mathrm{~N}_{6} \mathrm{~S}_{2}$. This preparation is a representative of the new class of medical substances - tiopoetins that regulate genetic and metabolic processes in cells and tissues, influencing immune resistance due to the modeling influence on intracellular processes of thiol metabolism [4]. The special feature of the preparation is the ability to the differentiated influence on normal and transformed (blastic, tumor) cells. The preparation doesn't disturb regulatory relations between humoral and cellular immunity links [4]. The analysis of clinical researches proves positive results of using this preparation in patients with oncologic diseases [5]. The normalizing influence of the preparation on the cellular regulation reaction, oxygen delivery to cells, intensity of the oxidative cellular metabolism, combined with the inflow of necessary amino acids causes the increase of normocytes resistance to endogenous and microbial toxins, chemotherapy (CT) components, favors the better course of the program therapy and faster treating effect in the clinic of the oncologic pathology [6]. Modern scientific studies in pulmonology also demonstrate the positive influence of glutamyl-cysteinyl-glycine disodium at chronic specific [7] and non-specific [8] pulmonary diseases including pneumonias [9]. We know studies that use functional changes of the immune reactivity state as indications for the beginning of ABT correction at pneumonias [10]. Some authors demonstrated the contribution of this preparation in more bio-availability to the effect of antibacterial preparations [11]. Scientific studies proved that glutamyl-cysteinyl-glycine disodium is the choice preparation for potentiation of the antibacterial effect of chemotherapeutic preparations and decrease of antibacterial resistance [11].

The diversity of intracellular and humoral regulatory effects of glutamyl-cysteinyl-glycine disodium, its positive influence on all links of the immune response in patients with leucosis with pneumonia manifestations and its possibility to influence non-differentiated malignant cells of the main disease, determined the choice of this preparation for elaborating the treating method of pneumonia in patients on AL background.

\section{Aim of research}

To analyze the influence of the immunomodeling preparation glutamyl-cysteinyl-glycine disodium on cellular and humoral immunity indices in patients with pneumonia on the background of AnonLL for forming new approaches to the improvement of treating pneumonias in patients with immunity disorders.

\section{Materials and methods}

The research group consisted of 37 patients with pneumonia, developed at the background of AnonLL, who underwent the program treatment according to the form and stage of the disease on the base of the hematological center "MI of city multi-profile clinical hospital No. 4", Dnipro city. The age of patients from the research groups was from 23 to 45 years; among them - 10 women and 27 men. The diagnosis of acute non-lymphoblast leucosis (AnonLL) was verified according to conventional clinical and morphological criteria, treatment protocol $-7+3[12]$; the diagnosis of pneumonia was verified according to modern clinical protocols of diagnostics and treatment [13].

Patients were divided in two groups. Patients of the main research $(n=18)$ were additionally prescribed with glutamyl-cysteinyl-glycine disodium by the scheme $2 \mathrm{ml}$ of $3 \%$ solution $(60 \mathrm{mg}) \mathrm{i} / \mathrm{v}$ No. 5 each second day, on the background of the traditional ABT according to standards of pneumonia treatment. Preparation administration in morning hours, summary dose was $300 \mathrm{mg}$. Patients of comparison $(\mathrm{n}=19)$ underwent the pneumonia treatment without immunomodeling preparations inclusion. The man age of the main group was $28,0(24,5 ; 34,5)$ years, age of patients from the group of comparison - 29,5 (24,5; 32,5) (Me $(25 \% ; 75 \%))$. The number of men and women in the main group -3 and 15; in the control one -5 and 14 , respectively. The control 
group contained 20 practically healthy donors (10 men and 10 women), which immunogram indices were compared with ones of the immune reactivity of patients at the end of treatment.

All patients underwent the study of immune response indices. The determination of cellular immunity indices (T-lymphocytes, B-lymphocytes and subpopulation composition (CD3+, CD4+, $\mathrm{CD} 8+, \mathrm{CD} 19+, \mathrm{CD} 16+, \mathrm{CD} 56+$ ) was realized using the flowing laser cytofluorimetry (BeckmanCoulter-USA). The immunoregulatory index of T-helpers $(\mathrm{CD} 3+\mathrm{CD} 4+) / \mathrm{T}$ cytotoxic $(\mathrm{CD} 3+\mathrm{CD} 8+)$, leuco T-cellular (leucocytes/CD3+), leuco B-cellular (leucocytes/CD19+), and the activation index of leucocytes (CD3+HLA-DR+) were additionally assessed. For assessing the functional-metabolic activity of blood neutrophils there were studied: phagocytic number (PN) and phagocytic index (PI). The state of neutrophils oxygen killing was assessed by the results of the spontaneous NBT-test with nitrablue tetrazolium. The study of humoral immunity indices was realized by determining immunoglobulins of A, G, M classes by the method of simple radial immunodiffusion. The research material was venous blood, taken from the cubital vein in morning only at the empty stomach, in the vacuum system to the set mark. K2EDTA was used as a coagulant. For obtaining correct results, according to the research method, after taking blood, the test tube with a sample was slowly turned 8-10 times for mixing blood with coagulant. It was stored and transported to the laboratory at the temperature $18-23{ }^{\circ} \mathrm{C}$ in the vertical position during $2-4$ hours (maximally permitted no more than 1 day). Indications of immunograms of patients from the research group were assessed in the treatment dynamics. There were also assessed: the clinical course of the disease, period of the intoxication syndrome regression, period of the body temperature normalization, dynamics of key indications of the hemogram, dynamics of rontgenological picture, general number of ABT days, necessity in its modification and possibility to return to the program treatment of the main disease depending on AnonLL stage. The statistical processing of research results was realized using methods of the descriptive and analytic biostatistics, realized in packages of program products STATISTICA 6.1 (StatSoftInc., serial No. AGAR909E415822FA); Microsoft Excel (Office Home Business 2KB4Y-6H9DB-BM47K-749PV-PG3KT) with the program superstructure AtteStat; program package MedCalc Statistical Software trial version 17.4. For describing quantitative signs, the median (Me) was used as a measure of the central tendency; interquartile scale ( $25 \%$; $75 \%$ - 25 and 75 percentiles correspondingly Q1 and Q3 - first and third quartiles) for describing signs variations; $95 \%$ reliable interval (95\% RI) for determining the diapason of median values in the general totality. The assessment of the reliability of differences of mean values for quantitative signs, taking into account their mainly asymmetric distribution, was realized by Mann-Whitney criteria (U) for non-connected samples and Wilcoxon criterion (W) for connected samples. The statistically reliable value of the significance level was considered as $p<0,05(5 \%)$ [14].

\section{Results of research}

The mean age of patients from the main group was $28,0(24,5 ; 34,5)$ years, patients of the comparison group - 29,5 $(24,5 ; 32,5)$. These indices didn't essentially differ in the research groups $(p=0,995)$. In the main group and comparison one were: patients in the stage "primary attack" -8 and 7 ; in the stage "remission" -9 and 11, respectively; in the stage "repeated relapse" -1 and 1 patients. Pneumonia characteristics: in the main and comparison groups of patients pneumonia appeared on the background of neutropenia - in 7 and 8 patients; on the background of anemia of I-II degree - in 5 and 6 patients; on the background of III-IV degree - in 13 and 13 patients, respectively. Patients with one-side lesion of lungs in the main group and comparison one: 7 and 7 patients; with two-side lesion of lungs: 11 and 12 patients, respectively; with pleurisy -5 and 6 patients, respectively. Pneumonia was diagnosed during 5 days of staying at hospital in the main and comparison groups: in 8 and 9 patients; after 5 days of staying in 10 and 10 patients, respectively. Thus, the analysis of comparability of comparison groups proved their homogeneity by gender-age parameters that allow to compare them correctly by other studied parameters.

The results of the study of cellular and humoral immunity indices and phagocytosis state of patients with AnonLL at the initial stage of pneumonia treatment are presented in Table $\mathbf{1}$. 
Table 1

Cellular and humoral immunity indices and phagocytosis state of patients with nonLL at the initial stage of pneumonia treatment

\begin{tabular}{|c|c|c|c|c|}
\hline Indices Me (25 \%; $75 \%)$ & $\begin{array}{c}\text { Main group } \\
n=18\end{array}$ & $\begin{array}{c}\text { Comparison group } \\
\mathbf{n}=19\end{array}$ & $\begin{array}{c}\text { Control group } \\
\mathbf{n}=\mathbf{2 0}\end{array}$ & $\begin{array}{c}\text { Differences } \\
\text { between groups* }\end{array}$ \\
\hline Leucocytes, $\left(10^{9} / 1\right)$ &, $56(1,38 ; 3,45)$ & $2,94(1,74 ; 3,79)$ & $6,11(4,22 ; 8,46)$ & $\mathrm{p}_{1}=0,330 ; \mathrm{p}_{2}<0,001 ; \mathrm{p}_{3}<0,001$ \\
\hline Lymphocytes, \% & $26,92(24,4 ; 30,04)$ & $29,15(24,15 ; 35,35)$ & $34,7(33,71 ; 35,78)$ & $\mathrm{p}_{1}=0,176 ; \mathrm{p}_{2}<0,001 ; \mathrm{p}_{3}=0,004$ \\
\hline $\begin{array}{c}\text { B-cells } \\
(\mathrm{CD} 3-\mathrm{CD} 19+), \%\end{array}$ & $10,42(9,43 ; 11,86)$ & $9,4(7,5 ; 12,7)$ & $17,22(13,46 ; 19,38)$ & $\mathrm{p}_{1}=0,228 ; \mathrm{p}_{2}<0,001 ; \mathrm{p}_{3}<0,001$ \\
\hline $\begin{array}{c}\text { B-cells } \\
(\mathrm{CD} 3-\mathrm{CD} 19+), \mathrm{G} / 1\end{array}$ & $0,18(0,13 ; 0,4)$ & $0,13(0,09 ; 0,26)$ & $0,44(0,32 ; 0,52)$ & $\mathrm{p}_{1}=0,046 ; \mathrm{p}_{2}<0,001 ; \mathrm{p}_{3}<0,001$ \\
\hline T-cells (CD3+CD19-), \% & $52,03(43,98 ; 56,14)$ & $54,95(45,65 ; 58,45)$ & $71,79(65,52 ; 75,31)$ & $\mathrm{p}_{1}=0,381 ; \mathrm{p}_{2}<0,001 ; \mathrm{p}_{3}<0,001$ \\
\hline T-cells (CD3+CD19-), G/1 & $1,1(0,89 ; 1,78)$ & $1,04(0,57 ; 1,26)$ & $1,41(1,06 ; 1,73)$ & $p_{1}=0,064 ; p_{2}=0,363 ; p_{3}=0,014$ \\
\hline T-helpers (CD3+CD4+), \% & $30,29(28,39 ; 34,22)$ & $28,4(24,6 ; 32,2)$ & $38,13(36,51 ; 41,5)$ & $\mathrm{p}_{1}=0,147 ; \mathrm{p}_{2}<0,001 ; \mathrm{p}_{3}<0,001$ \\
\hline T-helpers $(\mathrm{CD} 3+\mathrm{CD} 4+), \mathrm{G} / 1$ & $0,72(0,66 ; 0,94)$ & $0,65(0,5 ; 1,04)$ & $0,91(0,58 ; 1,09)$ & $\mathrm{p}_{1}=0,394 ; \mathrm{p}_{2}=0,517 ; \mathrm{p}_{3}=0,132$ \\
\hline T-cytotoxic (CD3+CD8+), \% & $22,61(19,73 ; 27,42)$ & $21,95(19 ; 26,25)$ & $28,05(23,43 ; 29,88)$ & $p_{1}=0,606 ; p_{2}=0,003 ; p_{3}=0,001$ \\
\hline T-cytotoxic $(\mathrm{CD} 3+\mathrm{CD} 8+), \mathrm{G} / 1$ & $0,55(0,44 ; 0,77)$ & $0,29(0,21 ; 0,42)$ & $0,46(0,41 ; 0,57)$ & $\mathrm{p}_{1}<0,001 ; \mathrm{p}_{2}=0,021 ; \mathrm{p}_{3}<0,001$ \\
\hline Immunoregulatory index & $1,33(1,01 ; 1,91)$ & $1,3(1,23 ; 1,44)$ & $1,86(1,28 ; 2,35)$ & $\mathrm{p}_{1}<0,661 ; \mathrm{p}_{2}=0,003 ; \mathrm{p}_{3}=0,008$ \\
\hline NK-cells (CD3-CD16+CD56+), \% & $8,39(9,53 ; 11,1)$ & $7,81(6,3 ; 12,95)$ & $13,71(9,71 ; 18,73)$ & $\mathrm{p}_{1}=0,105 ; \mathrm{p}_{2}=0,010 ; \mathrm{p}_{3}<0,001$ \\
\hline NK-cells (CD3-CD16+CD56+), G/1 & $0,11(0,10 ; 0,18)$ & $0,12(0,11 ; 0,19)$ & $0,39(0,25 ; 0,52)$ & $\mathrm{p}_{1}=0,815 ; \mathrm{p}_{2}=0,708 ; \mathrm{p}_{3}<0,001$ \\
\hline $\begin{array}{c}\text { T-NK-cells } \\
(\mathrm{CD} 3+\mathrm{CD} 16+\mathrm{CD} 56+), \%\end{array}$ & $3,31(2,5 ; 4,2)$ & $3,36(2,5 ; 4,3)$ & $2,21(1,49 ; 4,28)$ & $p_{1}=0,915 ; p_{2}=0,608 ; p_{3}=0,445$ \\
\hline $\begin{array}{c}\text { T-NK-cells } \\
(\mathrm{CD} 3+\mathrm{CD} 16+\mathrm{CD} 56+), \mathrm{G} / 1\end{array}$ & $0,042(0,032 ; 0,05)$ & $0,04(0,03 ; 0,05)$ & $0,03(0,01 ; 0,04)$ & $p_{1}=0,204 ; p_{2}=0,207 ; p_{3}=0,146$ \\
\hline T-activated (CD3+HLA-DR+), \% & $2,07(1,18 ; 3,9)$ & $2,41(1,3 ; 3,95)$ & $3,33(1,48 ; 5,26)$ & $\mathrm{p}_{1}=0,355 ; \mathrm{p}_{2}=0,074 ; \mathrm{p}_{3}=0,301$ \\
\hline $\operatorname{Ig~A,~g/1~}$ & $1,49(1,24 ; 2,04)$ & $1,42(1,05 ; 1,61)$ & $2,94(2 ; 3,27)$ & $\mathrm{p}_{1}=0,204 ; \mathrm{p}_{2}<0,001 ; \mathrm{p}_{3}<0,001$ \\
\hline $\operatorname{Ig} \mathrm{M}, \mathrm{g} / 1$ & $0,9(0,79 ; 1,1)$ & $1,0(0,56 ; 1,17)$ & $1,55(1,28 ; 1,89)$ & $\mathrm{p}_{1}=0,424 ; \mathrm{p}_{2}<0,001 ; \mathrm{p}_{3}<0,001$ \\
\hline Ig G, g/l & $9,21(8,21 ; 10,95)$ & $9,0(6,17 ; 10,3)$ & $10,24(8,58 ; 11,92)$ & $\mathrm{p}_{1}=0,175 ; \mathrm{p}_{2}=0,237 ; \mathrm{p}_{3}=0,020$ \\
\hline Phagocytic activity, un & $26(23 ; 28)$ & $28,5(22 ; 37,5)$ & $60,83(47,55 ; 73,01)$ & $\mathrm{p}_{1}=0,251 ; \mathrm{p}_{2}<0,001 ; \mathrm{p}_{3}<0,001$ \\
\hline Phagocytic number, un & $3,4(2,7 ; 4,1)$ & $3,0(2,3 ; 4,1)$ & $6,57(4,84 ; 8,23)$ & $\mathrm{p}_{1}=0,456 ; \mathrm{p}_{2}<0,001 ; \mathrm{p}_{3}<0,001$ \\
\hline Spontaneous NBT-test, un & $5(4 ; 6)$ & $4(3 ; 5)$ & $8,63(6,33 ; 12,29)$ & $\mathrm{p}_{1}=0,004 ; \mathrm{p}_{2}<0,001 ; \mathrm{p}_{3}<0,001$ \\
\hline Stimulated NBT-test, un & $24(18 ; 27,5)$ & $23,5(15,5 ; 26,5)$ & $63,69(57,51 ; 68,36)$ & $\mathrm{p}_{1}<0,061 ; \mathrm{p}_{2}<0,001 ; \mathrm{p}_{3}<0,001$ \\
\hline
\end{tabular}

Note: *-differences between groups by Mann-Whitney U-criterion: $p_{1}$ - between the main group and comparison one; $p_{2}$ - between the main group and control one; $p_{3}$-between the comparison group and control one

As it can be seen on the table 1 there were observed no differences by indices of cellular and humoral immunity and phagocytosis state of patients of AnonLL research groups at the initial stage of pneumonia treatment. The decrease of the quantity of lymphocytes, T-helpers, T-inductors and T-cytoxic subpopulations and also B-lymphocytes and NK-cells was observed in both groups of patients. The obtained results coincide with data of other researchers [15]. It is understood, that comparing with the control group (healthy donors), most cellular and humoral immunity indices in 
patients of research groups reliably differed in relative values $\left(p_{1}<0,001\right)$, that testified to the evident disorder of all immunity links in patients with AnonLL. Any differences were not observed only by indices: T-helpers (CD3+CD4+) G/L, T-NK-cells (CD3+CD16+CD56+), T-activated $(\mathrm{CD} 3+\mathrm{HLA}-\mathrm{DR}+) \%$, that proved the impossibility of the inhibited immunity activation in patients with AnonLL as a response to pneumonia. Just the activation of these indicators must be manifested in patients with acute infectious complications (IC), including patients with pneumonias.

The research results of cellular immunity indices of patients with AnonLL at the final stage of pneumonia treatment at the background of pneumonia treatment with glutamyl-cysteinyl-glycine disodium are presented in Table 2.

Table 2

Cellular immunity indices of patients with AnonLL at the final stage of pneumonia treatment

\begin{tabular}{|c|c|c|c|c|}
\hline Indices Me (25 \%; $75 \%)$ & $\begin{array}{c}\text { Main group } \\
\mathrm{n}=18\end{array}$ & $\begin{array}{c}\text { Comparison group } \\
\mathrm{n}=19\end{array}$ & $\begin{array}{c}\text { Control group } \\
\mathbf{n}=\mathbf{2 0}\end{array}$ & Differences between groups * \\
\hline Leucocytes, $10^{9} / 1$ & $5,25(4,79 ; 7,74)$ & $4,34(3,08 ; 4,85)$ & $6,11(4,22 ; 8,46)$ & $\mathrm{p}_{1}<0,001 ; \mathrm{p}_{2}=0,872 ; \mathrm{p}_{3}=0,003$ \\
\hline Lymphocytes, $\%$ & $36,47(35,44 ; 38,57)$ & $31,8(29,65 ; 36,15)$ & $34,7(33,71 ; 35,78)$ & $\mathrm{p}_{1}<0,001 ; \mathrm{p}_{2}=0,005 ; \mathrm{p}_{3}=0,041$ \\
\hline $\begin{array}{c}\text { B-cells } \\
(\mathrm{CD} 3-\mathrm{CD} 19+), \%\end{array}$ & $19,07(16,84 ; 23,71)$ & $12,3(9,65 ; 15,1)$ & $17,22(13,46 ; 19,38)$ & $\mathrm{p}_{1}<0,001 ; \mathrm{p}_{2}=0,013 ; \mathrm{p}_{3}<0,001$ \\
\hline $\begin{array}{c}\text { B-cells } \\
(\mathrm{CD} 3-\mathrm{CD} 19+), \mathrm{G} / 1\end{array}$ & $0,27(0,19 ; 0,32)$ & $0,17(0,14 ; 0,32)$ & $0,44(0,32 ; 0,52)$ & $\mathrm{p}_{1}<0,001 ; \mathrm{p}_{2}=0,003 ; \mathrm{p}_{3}<0,001$ \\
\hline T-cells (CD3+CD19-), \% & $55,66(52,11 ; 57,19)$ & $57,8(49,6 ; 61,6)$ & $71,79(65,52 ; 75,31)$ & $\mathrm{p}_{1}=0,300 ; \mathrm{p}_{2}<0,001 ; \mathrm{p}_{3}<0,001$ \\
\hline T-cells (CD3+CD19-), G/1 & $1,29(1,11 ; 1,86)$ & $1,31(1,06 ; 1,88)$ & $1,41(1,06 ; 1,73)$ & $\mathrm{p}_{1}=0,230 ; \mathrm{p}_{2}<0,001 ; \mathrm{p}_{3}=0,933$ \\
\hline T-helpers (CD3+CD4+), \% & $39,73(36,23 ; 42,64)$ & $29,85(27,9 ; 33,15)$ & $38,13(36,51 ; 41,5)$ & $\mathrm{p}_{1}<0,001 ; \mathrm{p}_{2}=0,739 ; \mathrm{p}_{3}<0,001$ \\
\hline T-cytotoxic (CD3+CD8+), \% & $24,05(21,29 ; 27,04)$ & $24,25(20,85 ; 28,55)$ & $28,05(23,43 ; 29,88)$ & $p_{1}=0,966 ; p_{2}=0,008 ; p_{3}=0,033$ \\
\hline Immunoregulatory index & $1,56(1,41 ; 1,92)$ & $1,92(1,11 ; 3,38)$ & $1,86(1,28 ; 2,35)$ & $\mathrm{p}_{1}<0,001 ; \mathrm{p}_{2}=0,016 ; \mathrm{p}_{3}=0,638$ \\
\hline $\begin{array}{c}\text { NK-cells } \\
(\mathrm{CD} 3-\mathrm{CD} 16+\mathrm{CD} 56+), \%\end{array}$ & $14,1(12,93 ; 16,34)$ & $11,3(9,65 ; 13,5)$ & $13,71(9,71 ; 18,73)$ & $\mathrm{p}_{1}<0,001 ; \mathrm{p}_{2}=0,691 ; \mathrm{p}_{3}=0,110$ \\
\hline $\begin{array}{c}\text { T-NK-cells } \\
(\mathrm{CD} 3+\mathrm{CD} 16+\mathrm{CD} 56+), \%\end{array}$ & $4,48(3,12 ; 6,94)$ & $3,6(2,6 ; 4,65)$ & $2,21(1,49 ; 4,28)$ & $\mathrm{p}_{1}<0,001 ; \mathrm{p}_{2}<0,001 ; \mathrm{p}_{3}=0,152$ \\
\hline $\begin{array}{c}\text { T-activated } \\
(\mathrm{CD} 3+\text { HLA-DR+), \% }\end{array}$ & $1,57(1,25 ; 1,98)$ & $3,1(1,45 ; 5,1)$ & $3,33(1,48 ; 5,26)$ & $p_{1}=0,003 ; p_{2}=0,008 ; p_{3}=0,925$ \\
\hline $\begin{array}{c}\text { T-activated } \\
(\mathrm{CD} 3+\text { HLA-DR+), G/1 }\end{array}$ & $0,07(0,04 ; 0,09)$ & $0,05(0,04 ; 0,06)$ & $0,01(0,01 ; 0,03)$ & $p_{1}=0,003 ; p_{2}=0,001 ; p_{3}<0,001$ \\
\hline
\end{tabular}

Note: *-differences between groups by Mann-Whitney U-criterion: $p_{1}$ - between the main group and comparison one; $p_{2}$ - between the main group and control one; $p_{3}$-between the comparison group and control one

The analysis of the cellular immunity state of patients of research groups (Table 2, 3) demonstrated the reliable $(p<0,05)$ changes of most indices took place on the background of the treatment that indicated the positive influence of the prescribed treatment. The immunoregulatory index and T-helpers $(\mathrm{CD} 3+\mathrm{CD} 4+), \%$ were reliable increased in the main group $(p=0,001)$ and stable in comparison ones $(p=0,682)$ (Table 1). At comparing the cellular immunity link in patients of the main and comparison groups at the end of the treatment, it was revealed, that differences were rather essential and reliably differed from each other in favor to indices of the main group (Table 2). The analysis of cellular immunity indices distribution in patients of the research groups relative to referent (normative) values proved the essential $(\mathrm{p}<0,05)$ approximation to norms in the main group of patients: lymphocytes (\%), B-cells (CD3-CD19+) (\%), T-helpers (CD3+CD4+) (\%), T-cytotoxic 
$(\mathrm{CD} 3+\mathrm{CD} 8+)(\%)$ and $\mathrm{T}-\mathrm{NK}-$ cells $(\mathrm{CD} 3+\mathrm{CD} 16+\mathrm{CD} 56+)(\%)$. The reliable approximation to referent values wasn't observed in patients from the comparison group by these indices.

The results of the study of humoral immunity indices and phagocytosis state in patients from the research groups at the final stage of pneumonia treatment are presented in Table $\mathbf{1 .}$

Table 3

Humoral immunity indices and phagocytosis state in patients with AnonLL at the final stage of pneumonia treatment

\begin{tabular}{ccccc}
\hline Indices Me (25 \%; $\mathbf{7 5} \%)$ & Main group $\mathbf{n = 1 8}$ & Comparison group $\mathbf{n = 1 9}$ & Control group $\mathbf{n}=\mathbf{2 0}$ & Differences between groups* \\
\hline Ig A, g/l 000 & $2,33(1,77 ; 2,78)$ & $1,85(1,54 ; 1,96)$ & $2,94(2 ; 3,27)$ & $\mathrm{p}_{1}=0,002 ; \mathrm{p}_{2}=0,095 ; \mathrm{p}_{3}=0,001$ \\
Ig M, g/1 & $1,61(1,18 ; 1,77)$ & $1,14(1 ; 1,46)$ & $1,55(1,28 ; 1,89)$ & $\mathrm{p}_{1}=0,001 ; \mathrm{p}_{2}=0,675 ; \mathrm{p}_{3}=0,004$ \\
Ig G, g/1 & $10,94(9,81 ; 11,89)$ & $9,77(8,35 ; 12,08)$ & $10,24(8,58 ; 11,92)$ & $\mathrm{p}_{1}=0,359 ; \mathrm{p}_{2}=0,484 ; \mathrm{p}_{3}=0,565$ \\
$\begin{array}{l}\text { Phagocytic } \\
\text { activity, un }\end{array}$ & $34(25 ; 43)$ & $29(23 ; 33,5)$ & $60,83(47,55 ; 73,01)$ & $\mathrm{p}_{1}=0,039 ; \mathrm{p}_{2}<0,001 ; \mathrm{p}_{3}<0,001$ \\
$\begin{array}{l}\text { Phagocytic } \\
\text { number, un }\end{array}$ & $4,7(3,6 ; 5,1)$ & $3,25(2,65 ; 4,45)$ & $6,57(4,84 ; 8,23)$ & $\mathrm{p}_{1}=0,006 ; \mathrm{p}_{2}<0,001 ; \mathrm{p}_{3}<0,001$ \\
$\begin{array}{l}\text { Spontaneous } \\
\text { NBT-test, un }\end{array}$ & $6(5 ; 7)$ & $4(3,05 ; 5)$ & $8,63(6,33 ; 12,29)$ & $\mathrm{p}_{1}<0,001 ; \mathrm{p}_{2}=0,004 ; \mathrm{p}_{3}<0,001$ \\
$\begin{array}{c}\text { Stimulated } \\
\text { NBT-test, un }\end{array}$ & $25(18 ; 28)$ & $33,5(26,5 ; 40)$ & $63,69(57,51 ; 68,36)$ & $\mathrm{p}_{1}<0,001 ; \mathrm{p}_{2}<0,001 ; \mathrm{p}_{3}<0,001$
\end{tabular}

Note: *-differences between groups by Mann-Whitney U-criterion: $p_{1}$ - between the main group and comparison one; $p_{2}-$ between the main group and control one; $p_{3}$-between the comparison group and control one

As we can see from the data, presented in Table 3, humoral immunity indices - IgA and $\operatorname{IgM}$ - reliably increased in the main group of observation $(p<0,002$ and $p<0,001)$ in the treatment dynamics. IgA and IgM indices changed no reliably in patients from the comparison groups. The analysis of $\operatorname{IgA}$ and $\operatorname{IgM}$ indices distribution in patients from the research groups relative to referent (normative) values proved the essential $(\mathrm{p}<0,05)$ approximation to norms only in the main group of patients. PA and PN, spontaneous and stimulated NBT-test indices (that characterized phgocytosis activity) increased in the treatment dynamics in the research groups. But PA and spontaneous NBT-test at the end of the treatment reliably $(p<0,001)$ increased only in the main research group. The dynamics of spontaneous and stimulated NBT-tests was characterized by the positive dynamics ( $\mathrm{p}<0,001$ and $\mathrm{p}<0,001$, respectively) only in the main research group. The reliable dynamics to normal values took place in these indices distribution also in the main research group, as opposite to the comparison one $(p>0,05)$, in which result essential differences $(p<0,001)$ were observed between these indices relative to the norm in research groups at the end of the treatment. IgG index at the final stage of pneumonia treatment in patients of the main and control were not reliable ( $\mathrm{p} \geq 0,05)$.

\section{Discussion of research results}

At studying the immune system state of patients from research groups we detected the immune imbalance, deepened the CT course by practically all indices of cellular and immunity links. The obtained data coincide with ones of the other authors [15]. At the analysis of the obtained data at the end of treatment in the research groups, it was determined, that the concomitant therapy of the acute infectious process in lungs in both research groups led to the positive result, proved by reliable $(p<0,05)$ changes of cellular and humoral immunity links of patients in the research groups. But comparing these indices between groups, it was determined, that they were reliably $(\mathrm{p}<0,05)$ higher in patients with the use of the immunemodeling preparation glutamyl-cysteinyl-glycine disodium. It is important to accent the fact that patients from the main research group had also reliably increased number of T-helpers $(\mathrm{CD} 3+\mathrm{CD} 4+)$ and immunoregulatory index. It was proved, 
that disorders of regulatory and effective functions of immunocompetent cells in patients with pneumonias are characterized with the change of balance of CD4+/CD8+ lymphocytes to the side of decrease of the helper and prevailing suppressor effect [16]. Thus, the reception of the renewal of the number of T-helpers (CD3+CD4+) and decrease of the suppressor effect in patients of the main group prove the expedience of using the immunolodeling preparation glutamyl-cysteinyl-glycine disodium for the positive influence on pathogenetic links of the immune imbalance development at pneumonias.

Under conditions of the immune system imbalance on the background of AL, the one on main tasks is the correction of diverse manefestations of the immune deficiency, including humoral one. It is important that $\operatorname{IgA}$ and $\operatorname{IgM}$ indices of patients of the main group differed not reliably from ones of the control group $(\mathrm{p}=0,095$ and $\mathrm{p}=0,675)$, respectively; whereas they differed reliably в $(p=0,001$ and $p=0,004)$ in patients from the control group. Thus, the analysis of $\operatorname{Ig} \mathrm{A}$ and $\operatorname{IgM}$ indices of patients from the main group testify to the reliable $(\mathrm{p}<0,005)$ approximation to indices of healthy people. $\operatorname{IgA}$ and $\operatorname{IgM}$ indices in patients of the comparison group didn't approximate to referent values even at the positive dynamics. Positive reliable changes of the humoral immunity in patients with AnonLL at the final pneumonia treatment stage by $\operatorname{Ig} \mathrm{A}$ and $\operatorname{IgM}$ indices and their approximation to the indices of healthy people are the desirable response of the immune system in patients with pneumonias. Because it is known, that IgM activates the system of enzymes that take part in the immune response realization and have the ability to intensify phagocytosis indices. IgA is responsible for infectious agents and bacterial toxins neutralization. Just these immunomodeling effects of glutamyl-cysteinyl-glycine disodium were expected in this research. IgG index dynamics in patients of the research groups at the final stage of pneumonia treatment were not reliable, because IgG are so-called late antibodies.

Thus, the results of the research proved the positive dynamics of indices of cellular and humoral immunity links and phagocytosis state in patients with pneumonias on the background of using glutamyl-cysteinyl-glycine disodium preparation. The obtained research results coincide with the data of our previous researches [17] and ones of the other authors. The inclusion of glutamyl-cysteinyl-glycine disodium in COPD therapy favored the growth of the number of mature T-lymphocytes, T-helpers, cytotoxic cells in peripheral blood [8]. Patients with out-hospital pneumonia with immunodeficiency signs at using glutamyl-cysteinyl-glycine disodium also demonstrated the positive clinical effect, associated with the shortening of patient's staying at hospital [11]. The researches demonstrated the effect of this preparation by favoring more subjectability to antibacterial preparations effect. It also favors the increase of CT means effectiveness by changing the activity of membrane transporters of resistance to chemotherapeutic preparations [19]. These effects of glutamyl-cysteinyl-glycine disodium were realized in our research at clinic by the decrease of days of AB load and faster return to the program treatment.

According to clinical researches, glutamyl-cysteinyl-glycine disodium decreases terms of resorption of infiltrative and nidal changes in lungs on the background of the increase of the number of mature T-lymphocytes, T-helpers, cytotoxic cells in peripheral blood in patients with the specific pulmonary inflammation [11]. The positive effects of using glutamyl-cysteinyl-glycine disodium are the decrease of expenditures of treatment of patients, including shortening of staying at hospital, decrease of reserve preparations and concomitant therapy means consumption [20].

Thus, our results that indicate the reliable positive dynamics of indices of cellular and humoral immunity links and activation of indices of anti-infectious defense, persuasively testify the possibility of using immunomodeling preparation glutamyl-cysteinyl-glycine disodium for improving the treatment schemes for patients with pneumonias at the background of AnonLL.

Our research was realized on the small number of patients. It is caused by the malignant course of the main disease. Today the question as to the immunomodeling therapy use at pneumonias in patients with immunity disorders, including on the background of oncological diseases of blood, must be the subject of a separate discussion and additional scientific researches. 


\section{Conclusions}

1. The peculiarities of immunological reactivity state in patients with different forms of hemoblastosis, including AnonLL, become the pathogenetic background of diverse infectious complications, including pneumonias that are often causes of death. That is why the strategy of using only ethiotropic therapy at pneumonias in patients with AnonLL doesn't lead to expecting results. The necessity of improving treatment schemes of pneumonias on the background of AnonLL conditions the inclusion of preparations with the immunomodeling effect on the different immunity links of a patient.

2. The analysis of the research results proved the positive dynamics of indices of the cellular immunity link of patients with AnonLL on the background of the pneumonia treatment, manifested by reliable $(p<0,05)$ changes by almost all indices of the cellular immunity in the research group with the use of immunomodeling preparation glutamyl-cysteinyl-glycine disodium. The approximation of the immunoregulatory index and other indices of the cellular immunity link of patients with AnonLL of the main group to the ones of healthy people is the desirable response of the immune system of patients with pneumonias at the background of AnonLL.

3. The results of this research proved the positive dynamics of humoral immunity indices by reliable changes of $\operatorname{IgA}$, responsible for infectious agents and bacterial toxins neutralization, and IgM, that activates phagocytosis in patients with AnonLL at using immunomodeling preparation glutamyl-cysteinyl-glycine disodium in the pneumonia treatment scheme.

4. The increase of indices of phagocytic activity, phagocytic number and NBT-test in patients with AnonLL with pneumonias at using glutamyl-cysteinyl-glycine disodium testifies to the intensification of neutrophil granulocytes activity at system bacterial infectious diseases - pneumonias. This fact proves the possibility of improving pneumonia treating schemes in patients with severe immunity disorders using the immunomodeling preparation glutamyl-cysteinyl-glycine disodium.

\section{References}

[1] Helfond, V. M. (2009). Infektsionnye oslozhneniya u onkologicheskikh bol'nykh. Praktycheskaia onkolohyia, 10 (3), 141-146.

[2] Tretiak, N. M., Horiainova, N. V., Rybalska, A. P., Basova, O. V. (2007). Alhorytm terapii suprovodu pry hostrykh leikemiiakh. Onkoloyia, 9 (3), 258-261.

[3] Dziublyk, Ia. O. (2010). Klinichni aspekty antybiotykorezystentnosti zbudnykiv nehospitalnykh infektsii dykhalnykh shliakhiv. Ukrainskyi pulmonolohichnyi zhurnal, 3, 53-56.

[4] Kozhemiakyn, L. A. (2002). Mekhanizmy deystviya preparata Hlutoksim. Opportunisticheskie infektsii: problemy i perspektivy. Omsk: Omskaia medytsynskaia akademyia, 50-53.

[5] Grinevich, Yu. A. (2003). Immunoterapiya v protivoopukholevom i protivoretsidivnom lechenii onkologicheskikh bol'nykh. Doctor, 4, 32-34.

[6] Feshchenko, Iu. Y., Yshchuk, S. H., Matvyenko, Iu. A. (2012). Terapevticheskie vozmozhnosti innovatsionnogo immunomodulyatora v pul'monologii i ftiziatrii. Ukrainskyi pulmonolohichnyi zhurnal, 3, 50-54.

[7] Iablonskyi, P. K., Aizykov, D. L., Balasaniants, H. S. (2011). Raschet potentsial'noy kliniko-ekonomicheskoy effektivnosti ispol'zovaniya preparata Hlutoksym ${ }^{\circledR}$ vo fizioterapii. Biulleten VSNTs SO RAMN, 2, 260-261.

[8] Vakhnenko, A. V., Moisieieva, N. V. (2013). Zastosuvannia suchasnoho imunomoduliatora pry zahostrenni khronichnoho obstruktyvnoho zakhvoriuvannia lehen. Svit medytsyny ta biolohii, 4 (41), 14-19.

[9] Mostovoi, Yu. M. (2013). Dosvid zastosuvannia imunomodeliuiuchoi terapii Hlutoksymom u khvorykh iz tiazhkym perebihom nehospitalnoi pnevmonii. Zdorov'ia Ukrainy, 23, 52-53.

[10] Pertseva, T. O., Kireieva, T. V., Bielosludtseva, K. O. (2013). Kliniko-imunolohichne obgruntuvannia zastosuvannia imunomoduliatoriv u kompleksnii terapii tiazhkoi nehospitalnoi pnevmonii. Suchasni preparaty ta tekhnolohii, 9-10, 15-18.

[11] Sokolova, H. B. et. al. (2002). Lechenye lekarstvenno- rezystentnoho tuberkuleza. Moscow, 15. 
[12] Standarty diahnostyky ta likuvannia onkolohichnykh khvorykh. Nakaz MOZ Ukrainy «Pro zatverdzhennia protokoliv nadannia medychnoi dopomohy za spetsialnistiu «Onkolohiia» vid 17.09.2007 r. No. 554 iz dopovnenniamy zghidno Nakazu MOZ Ukrainy No. 645 vid 30.07.2010 r. (2010). MOZ Ukrainy.

[13] Nehospitalna ta nozokomialna (hospitalna) pnevmoniia u doroslykh osib: etiolohiia, patohenez, klasyfikatsiia, diahnostyka, antybakterialna terapiia. Nakaz MOZ Ukrainy «Pro zatverdzhennia klinichnykh protokoliv nadannia medychnoi dopomohy za spetsialnistiu «Pulmonolohiia» vid 19.03.2007 r. No. 128 (2007). Kyiv: Veles, 105-146.

[14] Lanh, T. A., Sesyk, M. (2016). Kak opisyvat' statistiku v meditsine. Moscow: Praktycheskaia medytsyna, 480 .

[15] Smirnova, O. V., Manchuk, V. T. (2014). Features of immune cells in acute lymphoblastic leukemia. Medical Immunology, 15 (6), 577-584. doi: 10.15789/1563-0625-2013-6-577-584

[16] Parakhonskyi, A. P. (2017). Narushenyia immunnoi systemy u bolnykh pnevmonyei y metody ikh korrektsyi. Sovremennye problemy allerholohii i immunolohyi. Available at: http://econf.rae.ru/ article/534

[17] Borysova, I., Pertseva, T., Kaplan, P. (2017). Pat. No. 1007559 UA. Sposib likuvannia pnevmonii na tli hostrykh leikoziv. MPK A61K 31/451, A61R 31/00, A61R37/00. No. 201601587; declareted: 22.02.16; published: 12.06.17, Bul. No. 11, 8 .

[18] Feshchenko, Iu. Y., Rekalova, E. M. (2013). Osobennosti sovremennoi immunomodulyruiushchei terapii. Astma ta alerhiia, 1, 6-12.

[19] Vasyleva, S. N. (2007). Eksperymentalnoe obosnovanye ispolzovanyia Hlutoksyma ${ }^{\circledR}$ V kachestve sredstva soprovozhdenyia etyotropnoi terapii heneralzovannoho tuberkuleza. Saint Petersburg, 22.

[20] Sinitsyn, M. V., Bohadelnykova, Y. V., Perelman, M. Y. (2010). Hlutoksym - 10 let vo ftyzyatryy (opyt prymenenyia pri lechenii tuberkuleza). Tuberkulez i bolezni lehkykh, 10, 3-9. 